\title{
Precise Conductance Measurements on Dilute Aqueous Solutions of Sodium and Potassium Hydrogenphosphate and Dihydrogenphosphate
}

\author{
A. D. Pethybridge, ${ }^{1}$ J. D. R. Talbot, ${ }^{1,2, *}$ and W. A. House ${ }^{2}$
}

Received March 2, 2004; accepted September 23, 2005

Published Online: May 5, 2006

\begin{abstract}
Precise conductance measurements are reported on dilute aqueous solutions of the sodium and potassium salts of orthophosphoric acid at $25^{\circ} \mathrm{C}$. Conductance measurements on solutions of electrolytes such as these phosphate salts that exist in solution as complicated mixtures of ions have previously proved difficult to interpret. To overcome this, a mathematical method has been developed to calculate the concentrations of all the species in the aqueous system $\mathrm{M}_{3} \mathrm{PO}_{4} / \mathrm{M}_{2} \mathrm{HPO}_{4} / \mathrm{M}_{2} \mathrm{HPO}_{4} / \mathrm{H}_{3} \mathrm{PO}_{4}(\mathrm{M}=\mathrm{Na}$ or $\mathrm{K})$ over a continuous range of stoichiometries. The Lee-Wheaton conductance equation has been used to interpret the conductance of these multicomponent solutions in terms of the limiting ionic conductances and concentrations of all the ions in the solution. The limiting molar conductances of the ions $\mathrm{H}_{2} \mathrm{PO}_{4}^{-}$and $\mathrm{HPO}_{4}^{2-}$ and the ion-pair formation constants of these ions with sodium and potassium ions were determined.
\end{abstract}

This work has enabled the accurate determination of solution parameters for the important hydrogenphosphate ions in water and provides an excellent example of the use of an advanced conductance theory in the analysis of the conductance of multicomponent electrolyte systems.

KEY WORDS: Conductance; electrolyte; phosphate; hydrogenphosphate; Lee Wheaton; aqueous; self consistent.

\section{INTRODUCTION}

The principal merit of conductance measurements compared to many other physico-chemical techniques applied to electrolyte solutions is that they are much more precise. Also they do not require the addition of foreign species to stabilize certain solution properties during measurement such as ionic strength or $\mathrm{pH}$,

\footnotetext{
${ }^{1}$ Department of Chemistry, The University of Reading, Whiteknights, Reading RG6 6AD, England.

${ }^{2}$ Centre for Ecology and Hydrology, Winfrith Technology Centre, Winfrith Newburgh, Dorchester, Dorset DT2 8ZD, England.
} 
which may introduce other extraneous effects. The major disadvantage is that the measured conductance is the sum of the contributions from all the ions present and that the conductance of an individual ion is very sensitive to electrostatic and hydrodynamic interactions between it and all the other ions.

The precision of conductance measurements can be exploited by applying refinements in conductance theory, such as those embodied in the Lee-Wheaton equation $^{(1,2)} \mathrm{A}$ consequence of this is that not only is a more accurate depiction of real solutions available, but also the equation extends the concentration range which can be employed to calculate ionic properties reliably. Although it is a relatively simple procedure to analyze conductance measurements for 1:1 salts consisting only of the conducting species $\mathrm{M}^{+}$and $\mathrm{X}^{-}$, it is a much more complicated matter to interpret measurements on unsymmetrical and mixed electrolytes. For example, even $2: 1$ salts contain the conducting species, $\mathrm{M}^{2+}, \mathrm{X}^{-}$, and possibly the ion pair, $\mathrm{MX}^{+}$.

For aqueous solutions of salts of a weak acid or alkali there is also the possibility of hydrolysis of either the anion or cation to form extra species which are then capable of forming ion pairs with the counter ions. This has prevented the interpretation of the conductive properties of many ions that exist in aqueous solution in multicomponent equilibria with other species. These include many ions which are found in common inorganic salts such as carbonates, hydrogenphosphates and phosphates, borates, ammonium salts and organic acids.

In this work a means of evaluating the contribution to the overall conductance of hydrolyzed species and their corresponding ion-pairs was devised that could be used in conjunction with precise conductance measurements on salts of weak polyprotic acids. This has enabled the determination of the molar conductances and ion-pair formation constants of mono- and dihydrogenphosphate salts without the simplifications and consequent inaccuracies involved in assuming them to be simple electrolytes. The principles of the calculations of the concentrations of the different species are given below.

\section{SPECIATION CALCULATIONS}

The relative activities of the chemical species of a closed system of an electrolyte solution at a known temperature and in its most thermodynamically stable state are determined by a set of equilibrium constants. The system is also governed by three other requirements, namely those of electroneutrality, mass conservation and initial stoichiometry of the solid electrolyte. These constraints are dependent on the concentration of chemical species. A mathematical calculation of the concentration of species in solution must conform to all constraints and can only be satisfied by a unique set of values since composition is a state property.

Aqueous solutions of phosphate and hydrogenphosphate salts with the same counter ion, e.g., $\mathrm{Na}_{3} \mathrm{PO}_{4}, \mathrm{Na}_{2} \mathrm{HPO}_{4}, \mathrm{NaH}_{2} \mathrm{PO}_{4}$, and $\mathrm{H}_{3} \mathrm{PO}_{4}$, are defined by the 
same equilibria, electroneutrality and mass balance constraints with the sole difference being the stoichiometry of the system, i.e., the ratio $\mathrm{Na}$ Total $: \mathrm{P}_{\text {Total }}$.

In the subsequent treatment the metallic species is sodium but the derivation is equally valid for potassium or any other singly charged cation. The species considered in these calculations were as follows:

1. Simple cation $\mathrm{Na}^{+}$

2. Phosphate-containing species $\mathrm{H}_{3} \mathrm{PO}_{4}^{0}, \mathrm{H}_{2} \mathrm{PO}_{4}^{-}, \mathrm{HPO}_{4}^{2-}, \mathrm{PO}_{4}^{3-}$

3. Ion pairs containing one metal atom $\mathrm{NaH}_{2} \mathrm{PO}_{4}^{0}, \mathrm{NaHPO}_{4}^{-}, \mathrm{NaPO}_{4}^{2-}$, $\mathrm{NaOH}^{0}$

4. Products of solvolysis or dissociation $\mathrm{H}^{+}, \mathrm{OH}^{-}$.

Compound ions containing more than one metal ion, e.g., $\mathrm{Na}_{2} \mathrm{HPO}_{4}^{0}$ and $\mathrm{Na}_{2} \mathrm{PO}_{4}^{-}$were not considered. This is justifiable because these ion pairs are less electrostatically favored than the corresponding ion pair containing one metal atom (i.e., $\mathrm{NaHPO}_{4}^{-}$and $\mathrm{NaPO}_{4}^{2-}$ ) because of the smaller Coulombic forces between the pairing species as well as the low concentration of the contributing ion pair. s The equilibria considered were:

(i) Dissociation of phosphoric acid

$$
\begin{gathered}
\mathrm{H}_{3} \mathrm{PO}_{4}^{0} \rightleftharpoons \mathrm{H}^{+}+\mathrm{H}_{2} \mathrm{PO}_{4}^{-} \quad K_{1}=\frac{\left[\mathrm{H}^{+}\right]\left[\mathrm{H}_{2} \mathrm{PO}_{4}^{-}\right] y_{1} y_{2}}{\left[\mathrm{H}_{3} \mathrm{PO}_{4}^{0}\right]}=Q_{1} y_{1} y_{1} \\
\mathrm{H}_{2} \mathrm{PO}_{4}^{-} \rightleftharpoons \mathrm{H}^{+}+\mathrm{HPO}_{4}^{2-} \quad K_{2}=\frac{\left[\mathrm{H}^{+}\right]\left[\mathrm{HPO}_{4}^{2-}\right] y_{1} y_{2}}{\left[\mathrm{H}_{2} \mathrm{PO}_{4}^{-}\right] y_{1}}=Q_{2} y_{2} \\
\mathrm{HPO}_{4}^{2-} \rightleftharpoons \mathrm{H}^{+}+\mathrm{PO}_{4}^{3-} \quad K_{3}=\frac{\left[\mathrm{H}^{+}\right]\left[\mathrm{PO}_{4}^{3-}\right] y_{1} y_{3}}{\left[\mathrm{HPO}_{4}^{2-}\right] y_{2}}=\frac{Q_{2} y_{1} y_{2}}{y_{2}}
\end{gathered}
$$

(ii) Dissociation of sodium/anion ion pairs

$$
\begin{array}{r}
\mathrm{NaH}_{2} \mathrm{PO}_{4}^{0} \rightleftharpoons \mathrm{Na}^{+}+\mathrm{H}_{2} \mathrm{PO}_{4}^{-} \quad K_{4}=\frac{\left[\mathrm{Na}^{+}\right]\left[\mathrm{H}_{2} \mathrm{PO}_{4}^{-}\right] y_{1} y_{1}}{\left[\mathrm{NaH}_{2} \mathrm{PO}_{4}^{0}\right]}=Q_{4} y_{1} y_{1} \\
\mathrm{NaHPO}_{4}^{-} \rightleftharpoons \mathrm{Na}^{+}+\mathrm{HPO}_{4}^{2-} \quad K_{5}=\frac{\left[\mathrm{Na}^{+}\right]\left[\mathrm{HPO}_{4}^{2-}\right] y_{1} y_{2}}{\left[\mathrm{NaHPO}_{4}^{-}\right] y_{1}}=Q_{5} y_{2} \\
\mathrm{NaPO}_{4}^{2-} \rightleftharpoons \mathrm{Na}^{+}+\mathrm{PO}_{4}^{3-} \quad K_{6}=\frac{\left[\mathrm{Na}^{+}\right]\left[\mathrm{PO}_{4}^{3-}\right] y_{1} y_{3}}{\left[\mathrm{NaPO}_{4}^{2-}\right] y_{2}}=\frac{Q_{6} y_{1} y_{3}}{y_{2}} \\
\mathrm{NaOH}^{0} \rightleftharpoons \mathrm{Na}^{+}+\mathrm{OH}^{-} \quad K_{7}=\frac{\left[\mathrm{Na}^{+}\right]\left[\mathrm{OH}^{-}\right] y_{1} y_{1}}{\left[\mathrm{NaOH}^{0}\right]}=Q_{7} y_{1} y_{1}
\end{array}
$$


(iii) Self-dissociation of water

$$
\left.\mathrm{H}_{2} \mathrm{O} \rightleftharpoons \mathrm{H}^{+}+\mathrm{OH}^{-} \quad K_{w}=\left[\mathrm{H}^{+}\right] \mathrm{OH}^{-}\right] y_{1} y_{1}=Q_{w} y_{1} y_{1}
$$

where $K_{i}$ is the thermodynamic equilibrium constant and $Q_{i}$ is the equilibrium concentration quotient for a particular equilibrium and all concentrations are expressed in units of mol. $\mathrm{dm}^{-3}$ and $y_{1}, y_{2}$, and $y_{3}$ are the average molar activity coefficients of monovalent, divalent and trivalent ions, respectively. The activity coefficients of uncharged molecules are assumed to be unity, i.e., $y_{0}=1$. In this work the Davies equation was used to calculate values of $y_{1}, y_{2}$, and $y_{3}$. This equation has the form ${ }^{(3)}$ at $25^{\circ} \mathrm{C}$

$$
\log _{10} y_{z}=-\left(0.5115 z^{2}\right)\{\sqrt{I} /(1+\sqrt{I})-0.2 I\}
$$

where $I$ is the ionic strength of the solution in $\mathrm{mol} \cdot \mathrm{dm}^{-3}$ and $z$ is the charge number of the ion. Equilibrium constants were expressed as the dissociation constants rather than as ion-pair formation constants to avoid errors that can occur for species where ion-pair association is very small, e.g., $\mathrm{NaOH}^{0}$, which may arise as an association constant tends to zero.

Values of $K_{1}, K_{2}, K_{3}, K_{7}$, and $K_{w}$ were taken from the literature and are given in Table I. Values of $K_{4}$ and $K_{5}$ are determined in this work. Although included in the mathematical analysis, $K_{6}$ was set at zero because the amount of the $\mathrm{MPO}_{4}^{2-}$ ion pair was always negligible in our solutions.

The other constraints of the system are:

(a) Electroneutrality-the sum of all positive charges in a solution must be equal to the sum of all negative charges. i.e.,

$$
\begin{aligned}
{\left[\mathrm{M}^{+}\right]+\left[\mathrm{H}^{+}\right]=} & {\left[\mathrm{H}_{2} \mathrm{PO}_{4}^{-}\right]+2\left[\mathrm{HPO}_{4}^{2-}\right]+3\left[\mathrm{PO}_{4}^{3-}\right]+\left[\mathrm{MHPO}_{4}^{-}\right] } \\
& +2\left[\mathrm{MPO}_{4}^{2-}\right]+\left[\mathrm{OH}^{-}\right]
\end{aligned}
$$

Table I. Literature Values of Thermodynamic Equilibrium

Constants and Ionic Conductances Used in this Work

\begin{tabular}{lcc}
\hline & \multicolumn{1}{c}{ Value } & Reference \\
\hline$K_{1}$ & $7.112 \times 10^{-3} \mathrm{~mol} \cdot \mathrm{dm}^{-3}$ & 4 \\
$K_{2}$ & $6.345 \times 10^{-7} \mathrm{~mol} \cdot \mathrm{dm}^{-3}$ & 5 \\
$K_{3}$ & $1.09 \times 10^{-12} \mathrm{~mol} \cdot \mathrm{dm}^{-3}$ & 6 \\
$K_{7}$ & $5.0 \times 10^{0} \mathrm{~mol} \cdot \mathrm{dm}^{-3}$ & 7 \\
$K_{w}$ & $1.002 \times 10^{-14} \mathrm{~mol}^{2} \cdot \mathrm{dm}^{-6}$ & 8 \\
$\lambda_{0}\left(\mathrm{Na}^{+}\right)$ & $50.10 \mathrm{~S} \cdot \mathrm{cm}^{2} \cdot \mathrm{mol}^{-1}$ & 9 \\
$\lambda_{0}\left(\mathrm{~K}^{+}\right)$ & $73.54 \mathrm{~S} \cdot \mathrm{cm}^{2} \cdot \mathrm{mol}^{-1}$ & 9 \\
$\lambda_{0}\left(\mathrm{H}^{+}\right)$ & $349.71 \mathrm{~S} \cdot \mathrm{cm}^{2} \cdot \mathrm{mol}^{-1}$ & 10 \\
$\lambda_{0}\left(\mathrm{OH}^{-}\right)$ & $199.18 \mathrm{~S} \cdot \mathrm{cm}^{2} \cdot \mathrm{mol}^{-1}$ & 11 \\
\hline
\end{tabular}


(b) Mass balance - the amount of solute added to a closed solution is a fixed quantity. Therefore, in the case of a phosphate salt of sodium, the values of the total amount of phosphorus in the system, $P_{t}$, and sodium in the system, $M_{t}$, are the sums of the concentrations of all species containing that element. Therefore,

$$
\begin{gathered}
P_{\mathrm{t}}=\left[\mathrm{H}_{3} \mathrm{PO}_{4}^{0}\right]+\left[\mathrm{H}_{2} \mathrm{PO}_{4}^{-}\right]+\left[\mathrm{HPO}_{4}^{2-}\right]+\left[\mathrm{PO}_{4}^{3-}\right]+\left[\mathrm{MH}_{2} \mathrm{PO}_{4}^{0}\right] \\
+\left[\mathrm{MHPO}_{4}^{-}\right]+\left[\mathrm{MPO}_{4}^{2-}\right] \\
M_{\mathrm{t}}=\left[\mathrm{M}^{+}\right]+\left[\mathrm{MH}_{2} \mathrm{PO}_{4}^{0}\right]+\left[\mathrm{MHPO}_{4}^{-}\right]+\left[\mathrm{MPO}_{4}^{2-}\right]+\left[\mathrm{MOH}^{0}\right]
\end{gathered}
$$

In Eqs. (11) and (12) the terms from the sodium phosphate and sodium hydrogenphosphate ion pairs are self canceling and subtraction of Eq. (12) from (11) after rearrangement eventually yields, for example, to the expression

$$
\left[\mathrm{HPO}_{4}^{2-}\right]=\frac{Q_{1}\left[\mathrm{H}^{+}\right]^{2}\left(P_{t}-M_{t}\right)+Q_{1}\left[\mathrm{H}^{+}\right]\left(\left[\mathrm{H}^{+}\right]+Q_{w} / Q_{5}\right)}{\left[\mathrm{H}^{+}\right]^{3}+Q_{1}\left[\mathrm{H}^{+}\right]^{2}+Q_{1} Q_{2}\left[\mathrm{H}^{+}\right]+Q_{1} Q_{2} Q_{6}}\left[\mathrm{M}^{+}\right]
$$

in which $\left[\mathrm{HPO}_{4}^{2-}\right]$ is a linear function of $\left[\mathrm{M}^{+}\right]$.

Calculations are carried out in terms of equilibrium quotients $Q_{i}$ because they are directly related to the speciation in solution and to the mass and charge balance equations. It is the equilibrium constants, $K_{i}$, which must remain truly constant, however, and at each stage of the iteration a new set of $Q_{i}$ values must be calculated from the $K_{i}$ set via the activity coefficients.

The whole process is repeated with the adjusted quotients, $Q_{i}$, until selfconsistent values for the concentrations of every species are obtained. These concentrations are then used with the Lee-Wheaton conductance equation to calculate the conductance of the solution and compare it with the observed value.

\section{EXPERIMENTAL}

The conductance measurements were made with stirred, three-electrode, Barthel-type cells ${ }^{(12)}$ in a bath filled with silicone oil maintained at $(25.00 \pm$ $0.005){ }^{\circ} \mathrm{C}$ and monitored by a platinum resistance thermometer calibrated at the National Physical Laboratory. The cells used for these measurements on phosphate electrolytes had cell constants in the region of $3 \mathrm{~cm}^{-1}$ determined by measurements on aqueous solutions of potassium chloride. The cell constant was determined using the equations described by Wu et al. ${ }^{(13,14)}$ for the conductance of standard potassium chloride solutions. Four equations were used for comparison; these were those of Lind, Zwolenik and Fuoss ${ }^{(15)}$ Chiu and Fuoss, ${ }^{(16)}$ Justice, ${ }^{(17)}$ and Barthel et al. ${ }^{(18)}$ The cell conductance was determined by weight 
addition in the range $0-0.03 \mathrm{mmol} \cdot \mathrm{dm}^{-3}$ using seven points. The four equations were compared (corrected for the conversion in the IPTS $t_{68}$ to IPTS $t_{90}$ scales) with the first addition omitted as this was usually $0.1 \%$ lower than the other values and the mean taken for the cell constant. All points in all equations were within $\pm 0.0001_{5} \mathrm{~cm}^{-1}$.

The conductance was measured using a Wayne-Kerr B905 bridge to a precision of $\pm 0.02 \%$. Measurements were made at four frequencies, $f$, and were extrapolated to zero $1 / f$. The cell was filled with a known mass of water that had been purified by distillation and demineralization and kept under an atmosphere of nitrogen at all times. The initial solvent conductance was about $0.04 \mu \mathrm{S} \cdot \mathrm{cm}^{-1}$ and was subtracted from all subsequent measurements. Modification of the speciation calculations to allow for the fact that solvent conductance would be partly due to dissolved $\mathrm{CO}_{2}$ was investigated in a similar manner to work on the conductance of carbonate solutions by the same authors ${ }^{(19)}$ but it was found that this did not improve the fit so the simpler method of subtraction was used. All stock solutions were prepared by mass and handled under an inert atmosphere of oxygen-free nitrogen. The measured solutions were prepared by additions taken from one stock solution and one diluted stock solution. Electrolyte concentrations were calculated from the masses of the constituents assuming a linear concentration dependence of each solution density, i.e., $\rho=\rho_{o}+k c$. Values of $k$ for each salt were determined by measurements of the density of each stock solution.

The electrolytes used in this work were $\mathrm{NaH}_{2} \mathrm{PO}_{4}, \mathrm{Na}_{2} \mathrm{HPO}_{4}, \mathrm{Na}_{3} \mathrm{PO}_{4}$, $\mathrm{KH}_{2} \mathrm{PO}_{4}, \mathrm{~K}_{2} \mathrm{HPO}_{4}$, and $\mathrm{K}_{3} \mathrm{PO}_{4}$.

\subsection{Purification of Electrolyte Salts}

Sodium dihydrogenphosphate was purchased as the anhydrous salt of at least 99.95\% purity from B. D. H. Chemicals Ltd. The salt was ground to a fine powder and dried overnight at $105{ }^{\circ} \mathrm{C}$ in vacuo before use. Potassium dihydrogenphosphate of at least $99.99 \%$ purity was obtained from Aldrich Chemical Company Ltd. and was prepared before use in a manner similar to the sodium salt. Sodium and potassium monohydrogenphosphate were supplied by Aldrich Chemical Company Ltd. as anhydrous salts of at least $99.999 \%$ purity. Both salts were ground and dried in an identical manner to that used for the dihydrogenphosphates. Aristar phosphoric acid was purchased from Aldrich Chemical Company Ltd. as the $85 \%$ concentrated acid. The acid was used directly from the bottle in the preparation of diluted solutions that were standardized by a Gran titration ${ }^{(20)}$ and used to prepare solutions of the tertiary sodium and potassium salts by titrating a stoichiometric amount of high purity sodium or potassium hydroxide to give a ratio of $\mathrm{Na}$ or $\mathrm{K}: \mathrm{P}$ of 3:1.

Sodium and potassium hydroxides were obtained as the low-carbonate $(<0.4 \%)$ solids from Aldrich Chemical Company Ltd. The sodium hydroxide was supplied as the anhydrous hydroxide and potassium hydroxide as the hemihydrate. 
In the preparation of the tertiary phosphate salts and in standardization of phosphoric acid, all hydroxide solutions were prepared with $\mathrm{CO}_{2}$-free conductivity water under an atmosphere of dry nitrogen. Sodium and Potassium hydroxide solutions were standardized using Convol (BDH) solutions of $0.05 \mathrm{~mol} \cdot \mathrm{dm}^{-3}$ hydrochloric acid, which was standardized versus an $500 \mathrm{~cm}^{3}$ aqueous solution of $1.000 \mathrm{~g}$ sodium tetraborate decahydrate. A Gran plot was used in each case to determine the hydrochloric acid and potassium or sodium hydroxide concentration.

\section{RESULTS}

Conductance measurements of the phosphate salts are given in Tables II and III. The measured values for the hydrogen and dihydrogen phosphate salts are in good agreement with those of Tsurko et al. ${ }^{(21)}$ although the concentration ranges were different, e.g., see Fig. 1 given as an example for the potassium salts. The results for the dihydrogen salts are also in good agreement with those of Mason and Culvern. ${ }^{(2)}$ The molar conductances for both $\mathrm{Na}_{3} \mathrm{PO}_{4}$ and $\mathrm{K}_{3} \mathrm{PO}_{4}$ are higher than previous measurements with the largest difference at the lowest concentrations ${ }^{(21)}$ (Fig. 1). The recent results of Tsurko et al. ${ }^{(21)}$ are also higher than measurements made previously. ${ }^{(23,24)}$

\subsection{Computational Analysis of Conductance}

The conductance data were analyzed by a modified version of the program DSYMZ, ${ }^{(9,19)}$ which uses the Lee-Wheaton equation ${ }^{(1,2)}$ to fit experimental conductance measurements. The essential modifications of DSYMZ in this work were firstly, the inclusion of a subroutine to calculate the concentration of the individual

Table II. Conductance of Sodium Salts of Phosphoric Acid at $25^{\circ} \mathrm{C}$

\begin{tabular}{|c|c|c|c|c|c|}
\hline \multicolumn{2}{|c|}{$\mathrm{NaH}_{2} \mathrm{PO}_{4}$} & \multicolumn{2}{|c|}{$\frac{1}{2}\left(\mathrm{Na}_{2} \mathrm{HPO}_{4}\right)$} & \multicolumn{2}{|c|}{$1 / 3\left(\mathrm{Na}_{3} \mathrm{PO}_{4}\right)$} \\
\hline $\begin{array}{c}\mathrm{c} / \mathrm{mmol} \\
\mathrm{dm}^{-3}\end{array}$ & $\begin{array}{c}\Lambda / \mathrm{S} \cdot \mathrm{cm}^{2} . \\
\mathrm{mol}^{-1}\end{array}$ & $\begin{array}{c}\mathrm{C} / \mathrm{mmol} \\
\mathrm{dm}^{-3}\end{array}$ & $\begin{array}{c}\Lambda / \mathrm{S} \cdot \mathrm{cm}^{2} . \\
\mathrm{mol}^{-1}\end{array}$ & $\begin{array}{c}\mathrm{C} / \mathrm{mmol} \\
\mathrm{dm}^{-3}\end{array}$ & $\begin{array}{c}\Lambda / \mathrm{S} \cdot \mathrm{cm}^{2} . \\
\mathrm{mol}^{-1}\end{array}$ \\
\hline 0.3094 & 87.460 & 0.3662 & 104.23 & 0.0992 & 151.27 \\
\hline 0.7869 & 84.485 & 1.0120 & 100.88 & 0.1635 & 151.05 \\
\hline 1.3953 & 82.794 & 1.4510 & 99.404 & 0.1762 & 150.70 \\
\hline 1.8142 & 82.054 & 1.7974 & 98.434 & 0.2113 & 150.09 \\
\hline 2.5025 & 81.145 & 2.3645 & 97.073 & 0.3280 & 148.72 \\
\hline 3.4424 & 80.212 & 3.4589 & 94.952 & 0.5499 & 146.54 \\
\hline 4.2258 & 79.585 & 4.1822 & 93.771 & 0.8433 & 144.22 \\
\hline 5.0073 & 79.049 & 5.1956 & 92.340 & & \\
\hline 6.2410 & 78.342 & 6.0685 & 91.252 & & \\
\hline \multirow[t]{3}{*}{7.8589} & 77.562 & 7.2770 & 89.905 & & \\
\hline & & 8.6063 & 88.624 & & \\
\hline & & 10.2910 & 87.202 & & \\
\hline
\end{tabular}


Table III. Conductance of Potassium Salts of Phosphoric Acid at $25^{\circ} \mathrm{C}$

\begin{tabular}{|c|c|c|c|c|c|}
\hline \multicolumn{2}{|c|}{$\mathrm{KH}_{2} \mathrm{PO}_{4}$} & \multicolumn{2}{|c|}{$\frac{1}{2}\left(\mathrm{~K}_{2} \mathrm{HPO}_{4}\right)$} & \multicolumn{2}{|c|}{$1 / 3\left(\mathrm{~K}_{3} \mathrm{PO}_{4}\right)$} \\
\hline $\begin{array}{c}C / \mathrm{mmol} . \\
\mathrm{dm}^{-3}\end{array}$ & $\begin{array}{c}\Lambda / \mathrm{S} \cdot \mathrm{cm}^{2} . \\
\mathrm{mol}^{-1}\end{array}$ & $\begin{array}{c}C / \mathrm{mmol} . \\
\mathrm{dm}^{-3}\end{array}$ & $\begin{array}{c}\Lambda / \mathrm{S} \cdot \mathrm{cm}^{2} . \\
\mathrm{mol}^{-1}\end{array}$ & $\begin{array}{c}C / \mathrm{mmol} . \\
\mathrm{dm}^{-3}\end{array}$ & $\begin{array}{c}\Lambda / \mathrm{S} \cdot \mathrm{cm}^{2} . \\
\mathrm{mol}^{-1}\end{array}$ \\
\hline 0.0447 & 121.29 & 0.0484 & 132.57 & 0.0404 & 177.30 \\
\hline 0.1056 & 115.70 & 0.1557 & 129.58 & 0.1310 & 175.25 \\
\hline 0.1723 & 113.28 & 0.3145 & 127.58 & 0.1909 & 174.02 \\
\hline 0.2753 & 111.33 & 0.5031 & 126.11 & 0.2679 & 172.79 \\
\hline 0.3808 & 110.15 & 0.6639 & 125.15 & 0.3577 & 171.72 \\
\hline 0.5222 & 109.11 & 1.4291 & 121.94 & 0.6480 & 169.10 \\
\hline 1.1025 & 106.81 & 3.4870 & 116.99 & 1.1321 & 165.90 \\
\hline 2.3530 & 104.50 & 5.0287 & 114.51 & & \\
\hline 3.1204 & 103.62 & 7.5668 & 111.47 & & \\
\hline 4.3667 & 102.54 & 9.5533 & 109.60 & & \\
\hline 5.1063 & 101.98 & & & & \\
\hline 6.7214 & 100.97 & & & & \\
\hline
\end{tabular}

ions in solution by the method described in the preceding section on speciation calculations and secondly, the expansion of DSYMZ to fit conductance data for an eight-ion system.

Having omitted ion pairs containing more than one metal atom $\left(\mathrm{M}_{2} \mathrm{HPO}_{4}^{0}\right.$ and $\mathrm{M}_{2} \mathrm{PO}_{4}^{-}$), the mathematical treatment of the conductance data is one in which there are eighteen parameters. These are (i) eight equilibrium constants, (ii) the limiting molar conductances of eight ions, and (iii) the amount of material in solution, i.e., $N a_{t}\left(\right.$ or $\left.K_{t}\right)$ and $P_{t}$. The last named are known for each set of conductance measurements from the electrolyte concentration and stoichiometry. Of the other parameters, values at $25{ }^{\circ} \mathrm{C}$ for the equilibrium constants comprising the first, second and third dissociation constants of phosphoric acid ( $K_{1}, K_{2}$, and $K_{3}$ above), the dissociation of water $\left(K_{w}\right.$ above) and the ion pairing of $\mathrm{NaOH}$ or $\mathrm{KOH}\left(K_{7}\right.$ above) are all readily available (and are given in Table I) as are values at $25^{\circ} \mathrm{C}$ for the limiting molar conductance of the metal counter-ion $\left(\mathrm{Na}^{+}\right.$or $\left.\mathrm{K}^{+}\right)$and the products of solvolysis, $\mathrm{H}^{+}$and $\mathrm{OH}^{-}$at $25^{\circ} \mathrm{C}$.

For the ion pairs which are themselves conducting species there is the additional problem that it is impossible to determine the limiting molar conductances absolutely in the absence of the unpaired ions. Therefore, the limiting molar conductance of the conducting ion pairs, $\lambda_{0}\left(\mathrm{MHPO}_{4}^{-}\right)$, and $\lambda\left(\frac{1}{2} \mathrm{MPO}_{4}^{2-}\right)$, were fixed using geometric arguments as equal to $0.8 \lambda_{0}\left(\frac{1}{2} \mathrm{HPO}_{4}^{2-}\right)$ and $0.8 \lambda_{0}\left(1 / 3 \mathrm{PO}_{4}^{3-}\right)$ respectively, where $\mathrm{M}$ is $\mathrm{Na}$ or $\mathrm{K}$. This approximation had been found satisfactory in previous work on the application of the Lee-Wheaton equation to conductance measurements on 2:1 electrolytes. ${ }^{(9)}$

The mathematical analysis of the measurements therefore reduces to one in which there are six variables. These are the limiting molar conductance, and 

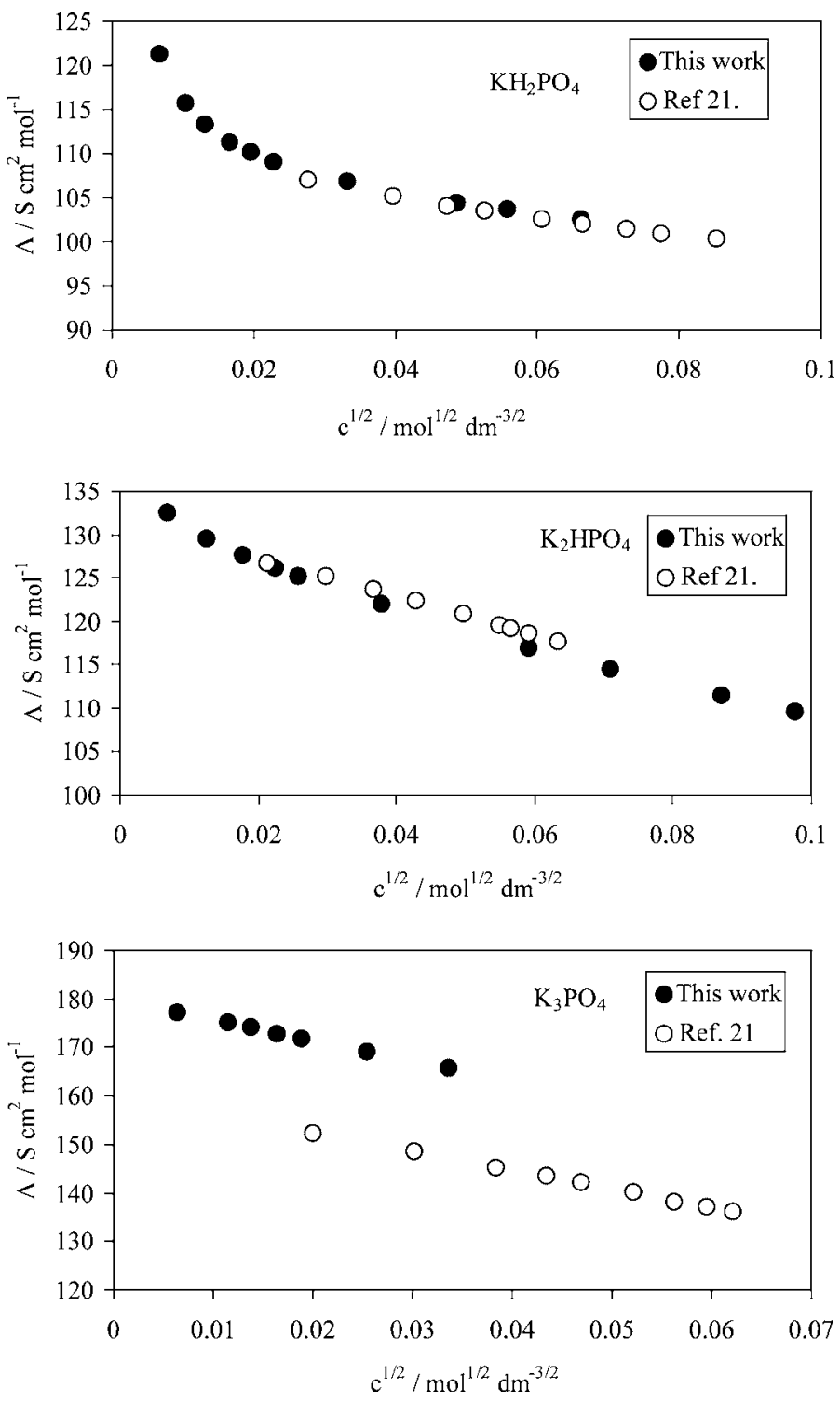

Fig. 1. Experimental molar conductivity of the potassium salts of orthophosphoric acid at $25^{\circ} \mathrm{C}$ obtained in this work compared with the data obtained by Tsurko et al. $^{(21)}$ 
ion-pair association constant with the metal counter-ion of (i) $\mathrm{H}_{2} \mathrm{PO}_{4}^{-}$, (ii) $\mathrm{HPO}_{4}^{2-}$ and (iii) $\mathrm{PO}_{4}^{3-}$. For a particular counter-ion $(\mathrm{Na}$ or $\mathrm{K}$ ) there are three sets of data, i.e., those carried out on the dihydrogen-, monohydrogen-, and orthophosphate salts, and in a perfect world analysis of conductance measurements analysis of each set would yield values of all six variables. In practice, however, it is necessary to adopt an iterative approach, determining only the limiting molar conductance and the ion pair formation constant of the dominant species.

The initial step of this process was to analyze the conductance data for the dihydrogen salt to obtain best-fit values for $\lambda_{0}\left(\mathrm{H}_{2} \mathrm{PO}_{4}^{-}\right)$and $K_{d}\left(\mathrm{MH}_{2} \mathrm{PO}_{4}^{0}\right)$. In this step the unknown parameters which govern the contribution of the other minor species in this solution, i.e., $\lambda_{0}\left(\frac{1}{2} \mathrm{HPO}_{4}^{2-}\right), K_{d}\left(\mathrm{MHPO}_{4}^{-}\right), \lambda_{0}\left(\frac{1}{3} \mathrm{PO}_{4}^{3-}\right)$, and $K_{d}\left(\mathrm{MPO}_{4}^{2-}\right)$, were estimated by comparison with other species of similar geometry and charge such as the sulphate and perchlorate ion. This gave preliminary values for $\lambda_{0}\left(\mathrm{H}_{2} \mathrm{PO}_{4}^{-}\right)$and $K_{d}\left(\mathrm{MH}_{2} \mathrm{PO}_{4}^{0}\right)$.

The next step was to perform a similar procedure with conductance data for the monohydrogen salt to obtain values for $\lambda_{0}\left(\frac{1}{2} \mathrm{HPO}_{4}^{2-}\right)$ and $K_{d}\left(\mathrm{MHPO}_{4}^{-}\right)$ using, for the parameters governing the conductance of the minor species, the values determined for $\lambda_{0}\left(\mathrm{H}_{2} \mathrm{PO}_{4}^{-}\right)$and $K_{d}\left(\mathrm{MH}_{2} \mathrm{PO}_{4}^{0}\right)$ in the first step and the same estimates for $\lambda_{0}\left(\frac{1}{3} \mathrm{PO}_{4}^{3-}\right)$ and $K_{d}\left(\mathrm{MPO}_{4}^{2-}\right)$.

The third step should have been to use these fitted values for $\lambda_{0}\left(\mathrm{H}_{2} \mathrm{PO}_{4}^{-}\right)$, $\lambda_{0}\left(\frac{1}{2} \mathrm{HPO}_{4}^{2-}\right), K_{d}\left(\mathrm{MH}_{2} \mathrm{PO}_{4}^{0}\right)$, and $K_{d}\left(\mathrm{MHPO}_{4}^{-}\right)$to calculate the contribution to the conductance of the secondary species in the aqueous solutions of the $\mathrm{M}_{3} \mathrm{PO}_{4}$ salts and hence fit the conductance of these solutions to determine a best-fit value for $\lambda_{0}\left(\frac{1}{3} \mathrm{PO}_{4}^{3-}\right)$ and $K_{d}\left(\mathrm{MPO}_{4}^{2-}\right)$. The measurements on $\mathrm{Na}_{3} \mathrm{PO}_{4}$ and $\mathrm{K}_{3} \mathrm{PO}_{4}$, however, proved impossible to fit, almost certainly because of the very small amount of phosphate ion, $\mathrm{PO}_{4}^{3-}$, actually present in these dilute solutions because of extensive hydrolysis. Therefore, there is even less of the phosphate ion pair, $\mathrm{MPO}_{4}^{2-}$. This would be expected to result in a disproportionate loading of any experimental errors on the parameters being fitted and preventing best-fit values for $\lambda_{0}\left(\frac{1}{3} \mathrm{PO}_{4}^{3-}\right)$ and $K_{d}\left(\mathrm{MPO}_{4}^{2-}\right)$ being obtained with any level of confidence. Higher concentrations could not be used to reduce the impact of this effect because of the restriction of the use of the Lee-Wheaton equation with highly charged ions to dilute solutions. Consequently, the limiting molar conductance of the phosphate ion, $\lambda_{0}\left(\frac{1}{3} \mathrm{PO}_{4}^{3-}\right)$, was ascribed a value of $80.0 \mathrm{~S} \cdot \mathrm{cm}^{2} \cdot \mathrm{mol}^{-1}$ - similar to that of the sulphate ion at $25^{\circ} \mathrm{C}$ - and the ion-pair association to form $\mathrm{MPO}_{4}^{2-}$ was neglected. Including it had no effect on the quality of fit of the conductance data for the other salts and negligible effect on the derived parameters. Similarly, small changes in the value assumed for $\lambda_{0}\left(\frac{1}{3} \mathrm{PO}_{4}^{3-}\right)$ had no significant effect on the fit or the derived parameters.

The final stage in the computer analysis of the conductance data was to recycle the calculated values for the limiting molar conductances of $\mathrm{H}_{2} \mathrm{PO}_{4}^{-}$and 
Table IV. Derived Parameters for Sodium and Potassium Salts of Phosphoric Acid at $25^{\circ} \mathrm{C}$

\begin{tabular}{lcccccc}
\hline & \multicolumn{2}{c}{$\mathrm{MH}_{2} \mathrm{PO}_{4}$} & & \multicolumn{2}{c}{$\mathrm{M}_{2} \mathrm{HPO}_{4}$} \\
\cline { 2 - 3 } \cline { 6 - 6 } & $\mathrm{Na}$ & $\mathrm{K}$ & & $\mathrm{Na}$ & $\mathrm{K}$ \\
\hline$\lambda_{0}\left(\mathrm{H}_{2} \mathrm{PO}_{4}^{-}\right) / \mathrm{S} \cdot \mathrm{cm}^{2} \cdot \mathrm{mol}^{-1}$ & 33.17 & 33.33 & & \\
$\lambda_{0}\left(\frac{1}{2} \mathrm{HPO}_{4}^{2-}\right) / \mathrm{S} \cdot \mathrm{cm}^{2} \cdot \mathrm{mol}^{-1}$ & & & & 57.60 & 57.57 \\
$K_{d}\left(\mathrm{MH}_{2} \mathrm{PO}_{4}^{0}\right) / \mathrm{mol}^{-1} \cdot \mathrm{dm}^{-3}$ & 0.56 & 0.50 & & \\
$K_{d}\left(\mathrm{MHPO}_{4}^{-}\right) / \mathrm{mol}^{-3} \cdot \mathrm{dm}^{-3}$ & & & & 0.021 & 0.046 \\
$\delta / \mathrm{S} \cdot \mathrm{cm}^{2} \cdot \mathrm{mol}^{-1}$ & 0.022 & 0.016 & & 0.015 & 0.018 \\
$R / \mathrm{nm}$ & 0.95 & 1.00 & & 0.21 & 0.19 \\
\hline
\end{tabular}

$\mathrm{HPO}_{4}^{2-}$ and the ion-pair dissociation constants for $\mathrm{MH}_{2} \mathrm{PO}_{4}^{0}$ and $\mathrm{MHPO}_{4}^{-}$until there was no significant change in the best-fit values obtained. Typically this was achieved after about four cycles. It was found that the best theoretical fit of the conductance data obtainable for some of the salts, i.e., the sodium and potassium monohydrogenphosphates, suffered from non-random error for values of the distance parameter, $R$, which correspond to a realistic physical minimum interionic distance, such as $R=0.5 \mathrm{~nm}$. Although the minimum standard deviations that were achieved in fitting the conductance data for these salts were very good, they occurred at a value of $0.206 \mathrm{~nm}$ for the sodium salt and $0.189 \mathrm{~nm}$ for the potassium salt. As the $\mathrm{P}-\mathrm{O}$ in phosphate is about $0.15 \mathrm{~nm}$, this is an unrealistic value for the distance of closest approach because the sum of the crystallographic radii should clearly exceed it.

The results of the best-fit calculations for sodium and potassium monohydrogen and dihydrogenphosphates are given in Table IV. These calculations were made with the $V_{2}$ and $C_{7}$ terms of the Lee-Wheaton equation included (even though they are regarded as possibly incomplete) ${ }^{(1,2)}$ as omission of either or both of them had a deleterious effect on the degree of fit. The effect of altering the distance parameter, $R$, in the Lee-Wheaton equation on the standard deviation of the fit achieved and on the limiting ionic conductances was small but the influence of $R$ on the value of the ion-pair formation constant for these salts was much larger. Therefore, the ion-pair dissociation constants are only recorded to two significant figures.

The values obtained for $\lambda_{0}\left(\mathrm{H}_{2} \mathrm{PO}_{4}^{-}\right)$and $\lambda_{0}\left(\mathrm{HPO}_{4}^{2-}\right)$ from the sodium and potassium salts in this work show excellent agreement $( \pm 0.3 \%$ and $\pm 0.1 \%$, respectively). As might be expected on simple electrostatic grounds, the ion-pair dissociation constants for the 1:1 species are larger than those for the 1:2 species in each case, i.e., the association of the 1:2 species is the greater. It is doubtful, however, whether much significance can be placed on the relative values of the $K_{d}$ values for the sodium and potassium ion pairs.

The calculated values of the limiting ion conductivities are close to those obtained by Tsurko et al. ${ }^{(21)}$ of $\lambda_{0}\left(\mathrm{H}_{2} \mathrm{PO}_{4}^{-}\right)=32.0 \mathrm{~S} \cdot \mathrm{cm}^{2} \cdot \mathrm{mol}^{-1}$ and $\lambda_{0}\left(\frac{1}{2} \mathrm{HPO}_{4}^{2-}\right)=$ 
$57.2 \mathrm{~S} \cdot \mathrm{cm}^{2} \cdot \mathrm{mol}^{-1}$ at $25{ }^{\circ} \mathrm{C}$ and within the range given by Mason and Culvern, ${ }^{(22)}$ 32.18-33.35 S. $\mathrm{cm}^{2} \cdot \mathrm{mol}^{-1}$, and Selvaratnam and Spiro, ${ }^{(25)}(32.9 \pm 1.0) \mathrm{S} \cdot \mathrm{cm}^{2}$. $\mathrm{mol}^{-1}$, for the dihydrogenphosphate ion at the same temperature. The results from Tsurko et al. ${ }^{(20)}$ were calculated using the Quint-Viallard equation ignoring the effects of ion-pair formation in solution. The calculation of $\lambda_{0}\left(\mathrm{H}_{2} \mathrm{PO}_{4}^{-}\right)$ from phosphoric acid data is complicated by the formation of three-ion species $\left\{\mathrm{H}_{2} \mathrm{PO}_{4} \cdot \mathrm{H} \cdot \mathrm{H}_{2} \mathrm{PO}_{4}\right\}^{-}$in this solution. This was proposed by Selveratnam and Spiro $^{(25)}$ as an explanation for the poor fit of their data on phosphoric acid when treated as a simple 1:1 electrolyte. Moreover, the hydrogen ion has a much higher ionic conductance (over $90 \%$ of the conductance of phosphoric acid is due to the hydrogen ions) and hence all the experimental error of the original work is loaded on to the anion conductance when $\lambda_{0}\left(\mathrm{H}^{+}\right)$is subtracted from $\Lambda_{0}\left(\mathrm{H}_{3} \mathrm{PO}_{4}\right)$.

\section{CONCLUSION}

It has proved possible to use conductance measurements to elucidate solution properties of species, namely hydrogenphosphate ions, which exist in aqueous media as mixtures. Therefore the usefulness of precision conductance measurements and their advantages compared to other techniques have been extended to electrolytes that have previously proved difficult to study because of their complexity.

\section{REFERENCES}

1. W. H. Lee and R. J. Wheaton, Conductance of Symmetrical, Unsymmetrical and Mixed Electrolytes. Part 1. Relaxation Terms, J. Chem. Soc., Farad. Trans. II, 74, 743-766 (1978).

2. W. H. Lee and R. J. Wheaton, Conductance of Symmetrical, Unsymmetrical and Mixed Electrolytes. Part 2. Hydrodynamic Terms and Complete Conductance Equation, J. Chem. Soc., Farad. Trans. II, 74, 1456-482 (1978).

3. C. W. Davies, The Extent of Dissociation of Salts in Water. VIII. An Equation for the Mean Ionic Activity Coefficient of an Electrolyte in Water, and a Revision of the Dissociation Constants of Some Sulfates. J. Chem. Soc. 2093-2098 (1938).

4. R. G. Bates, First Dissociation Constant of Phosphoric Acid from $0^{\circ}$ to $60^{\circ}$; Limitations of the Electromotive Force Method for Moderately Strong Acids. J. Res. Natl. Bur. Std. 47, 127-134 (1951).

5. R. G. Bates and S. F. Acree, $\mathrm{pH}$ of Aqueous Mixtures of $\mathrm{KH}_{2} \mathrm{PO}_{4}$ and $\mathrm{Na}_{2} \mathrm{HPO}_{4}$ at $0^{\circ}$ to $60^{\circ}$, J. Res. Natl. Bur. Std. 34, 373-394 (1945).

6. A. K. Ghosk, J. C. Ghosh, and B. Prasad, Third Dissociation Constant of Phosphoric Acid from 283.15 K to 323.15 K, J. Ind. Chem. Soc. 57, 1194-1199 (1980).

7. H. S. Harned and S. R. Scholes, The Ionization Constant of $\mathrm{HCO}_{3}{ }^{-}$from 0 to $50^{\circ}, J$. Am. Chem. Soc. 63, 1706-1709 (1941).

8. G. R. Gimblett and C. B. Monk, E.m.f. Studies of Electrolytic Dissociation. VII. Some Alkali and Alkaline Earth Metal Hydroxides in Water, Trans. Faraday Soc. 50, 965-972 (1954).

9. G. E. Cassford, The Temperature Dependence of the Conductance if Single and Mixed Electrolytes in Water, Ph.D. Thesis, University of f'Reading, 1983. 
10. L. E. Strong, Aqueous Hydrochloric Acid Conductance from 0 to $100{ }^{\circ} \mathrm{C}$, J. Chem. Eng. Data 25, 104-106 (1980).

11. K. N. Marsh and R. H. Stokes, Conductance of Dilute Aqueous $\mathrm{NaOH}$ Solutions from $15^{\circ}$ to $75^{\circ}$, Aust. J. Chem. 17, 740-749 (1964).

12. J. Barthel, R. Wachter, and H. J. Gores, in Modern Aspects of Electrochemistry, ed. B. E. Conway and J. O'M. Bockris (Plenum Publishing Corp., New York, p. 1. 1979.)

13. Y. C. Wu, W. F. Koch, W. J. Hamer, and R. L. Kay, Review of Electrolytic Conductance Standards, J. Solution Chem. 16, 985-997 (1987).

14. Y. C. Wu, W. F. Koch, W. J. Hamer, and R. L. Kay, An Update on the Electrolytic Conductivity Values for the Primary Standard Potassium Chloride Solutions: Conversion to the ITS-90 Temperature Scale, J. Solution Chem. 19, 1053-1054 (1990).

15. J. E. Lind Jr., J. J. Zwolenik, and R. M. Fuoss, Calibration of Conductance Cells at $25^{\circ}$ with Aqueous Solutions of Potassium Chloride, J. Am. Chem. Soc. 81, 1557-1559 (1959).

16. Y.-C. Chiu and R. M. Fuoss, Conductance of the Alkali Halides. XII. Sodium and Potassium Chlorides in Water at $25^{\circ}$. J. Phys. Chem. 72, 4123-4129 (1968).

17. J. C. Justice, Conductance of Symmetrical Electrolytes in Dilute Solution, J. Chim. Phys. 65, 353-356 (1968).

18. J. Barthel, F. Feuerlein, R. Neueder, and R. Wachter, Calibration of Conductance Cells at Various Temperatures, J. Solution Chem. 9, 209-219 (1980).

19. J. D. R. Talbot, The Conductivity of Carbonate and Phosphate Species in Aqueous Solution and in Some Related Natural Waters, Ph.D. Thesis, University of Reading, 1990.

20. G. Gran, Determination of the Equivalence Point in Potentiometric Titrations. II, Analyst 77, 661-671 (1952).

21. E. N. Tsurko, R. Neueder, J. Barthel, and A. Apelblat, Conductivity of Phosphoric Acid, Sodium, Potassium, and Ammonium Phosphates in Dilute Aqueous Solutions from 278.15 K to 308.15 K, J. Solution Chem. 28, 973-999 (1999).

22. C. M. Mason and J. M. Culvern, Electrical Conductivity of Orthophosphoric Acid and of Sodium and Potassium Dihydrogen Phosphates at $25^{\circ}$, J. Am. Chem. Soc. 71, 2387-2393 (1949).

23. C. Watkins and H. C. Jones, Conductivity and Dissociation of some Rather Unusual Salts in Aqueous Solution. J. Am. Chem. Soc. 37, 2626-2636 (1915).

24. H. C. Jones, The Electrical Conductivity, Dissociation and Temperature Coefficients of Conductivity (from Zero to Sixty-Five Degrees) of Aqueous Solutions of a Number of Salts and Organic Acids, Carnegie Institution of Washington, Publication No. 170, 1912.

25. M. Selvaratnam and M. Spiro, Transference Numbers of Orthophosphoric Acid and the Limiting Equivalent Conductance of the $\mathrm{H}_{2} \mathrm{PO}_{4}^{-}$Ion in Water at $25^{\circ}$, Trans. Faraday Soc. 61, 360-373 (1965). 